\title{
Effect of Irrigation Methods and Irrigation Levels on Yield and Water Productivity of Onion at Awash Melkasa, Ethiopia
}

\author{
Anbese Ambomsa ${ }^{1, ~ *}$, Teshome Seyoum², Tilahun Hordofa ${ }^{3}$ \\ ${ }^{1}$ Oromia Agricultural Research Institute, Adami Tulu Agricultural Research Center, Zeway, Ethiopia \\ ${ }^{2}$ Department of Irrigation Engineering, Haramaya University, Haramaya, Ethiopia \\ ${ }^{3}$ Ethipia Agricultural Research Institute, Melkasa Agricultural Research Center, Adama, Ethiopia
}

Email address:

anbeseambomsa@gmail.com (A. Ambomsa)

${ }^{*}$ Corresponding author

\section{To cite this article:}

Anbese Ambomsa, Teshome Seyoum, Tilahun Hordofa. Effect of Irrigation Methods and Irrigation Levels on Yield and Water Productivity of Onion at Awash Melkasa, Ethiopia. Industrial Engineering. Vol. 4, No. 2, 2020, pp. 33-42. doi: 10.11648/j.ie.20200402.12

Received: March 26, 2020; Accepted: April 16, 2020; Published: August 27, 2020

\begin{abstract}
Water is scarce resource in Central Rift Valley of Ethiopia and is major limiting factor for crop production. The field experiment was conducted in 2018 at Melkasa Agricultural Research Center during the off-season to identify irrigation method and irrigation application level that maximizes productivity of onion per unit of water consumed and enhanced onion crop production. The experiment was carried out using split plot design in RCBD having three replications. The experiment consisted of two irrigation methods viz., furrow and drip irrigation as main plot and three levels of manageable allowable depletion viz., $120 \%, 100 \%$ and $80 \%$ as sub-plot. The ANOVA revealed that their interaction had a significant $(\mathrm{p}<0.01)$ effect on bulb diameter, total bulb yield, marketable bulb yield and water productivity. The maximum total bulb yield (41.76 t/ha), marketable bulb yield $(38.39 \mathrm{t} / \mathrm{ha})$, bulb diameter $(6.02 \mathrm{~cm})$ and water productivity $\left(13.05 \mathrm{~kg} / \mathrm{m}^{3}\right)$ were observed from drip irrigation method at $80 \%$ management allowed depletion application, while significantly lower of $34.48 \mathrm{t} / \mathrm{kg}, 31.6 \mathrm{t} / \mathrm{ha}, 5.11$ $\mathrm{cm}$, and $6.84 \mathrm{~kg} / \mathrm{m}^{3}$ respectively were recorded from furrow irrigation method at $120 \%$ management allowed depletion application. Among all tested treatments drip irrigation method with $80 \% \mathrm{MAD}$ was the best practice because of its high yield, water productivity.
\end{abstract}

Keywords: Drip Irrigation, Furrow Irrigation, MAD, Onion, Water Productivity

\section{Introduction}

Water is man kind's most vital and versatile natural resource. It is also considered as an essential resource for irrigation. Irrigation is an artificial application of water to soil for the purpose of supplying the moisture essential in the plant root-zone to prevent stress that may cause reduced yield and/or poor quality of harvest of crops [1].

Irrigated agriculture is the largest water-consuming sector and it faces competing demands from other sectors, such as the industrial and the domestic sectors. With an increasing population and less water available for agricultural production, the food security for future generations is at stake. Hence the key challenge for future is growing more food with less water by way of increasing crop water productivity
(CWP). A higher CWP results in either the same production from fewer water resources, or a higher production from the same water resources, so this is of direct benefit for other water users [2].

The competition for existing freshwater supplies will require a paradigmatic shift from maximizing productivity per unit of land area to maximizing productivity per unit of water consumed [3].

Irrigation development is increasingly implemented in Ethiopia more than ever. Expansion of irrigated area combined with the efficient management of water will enhance the attainment of food security and poverty alleviation goals of the country. Although the country is well known for its vast water resources potential its erratic distribution both in space and time coupled with limited 
capacity is the most challenging problem that limited the contribution of the resources to the socio-economic development of the country [4].

Agricultural production particularly vegetable crops are intensively cultivated under irrigation in Central Rift valley (CRV) Ethiopia. The region is a semi-arid with limited water resources. Considering increasing demand for water combined with high evapotranspiration rates in the region, effective and efficient use of existing water resources need to be discovered.

Onion (Allium cepa L.) is one of the most important vegetable crops commercially grown in the world [5]. It is estimated that around the World, over 3,642,000 ha of onions are grown annually. On a worldwide scale, around 80 million metric tons of onions are produced per year [6]. It is also widely cultivated as source of income by many farmers in many places of Ethiopia. The country has a great potential to produce the crop throughout the year both for local consumption and export. The total area under onion production was estimated to be $24,375.7$ ha with an average yield of about 9.02 tons per hectare and estimated a total production of greater than 2, 19, 735.27 tons [7]. Traditionally, farmers in the CRV of Ethiopia have been using the most conventional surface irrigation system, most commonly the furrow irrigation system, for growing the crops. Furrow irrigation is characterized by low irrigation efficiency. The crop productivity under furrow irrigation can be achieved by applying the required amount at the right time. The crop is shallow rooted and sensitive to water stress. As a result it is commonly given light and frequent irrigation to avoid water stress [8].

Drip irrigation is one of the most efficient forms of irrigation technology currently available. It is a technology by which water can be conserved and yield increase for farmers, especially those who are cultivating in semi-arid conditions of the world or in areas where competition over water resources is escalating. Drip irrigation offers many advantage over furrow irrigation including water saving, reducing labor required for irrigation, reducing soil erosion and increasing crop productivity. Therefore, the efforts are now warranted to harness the available quantities of water and put them to efficient use to realize higher productivity per drop [9].

On-farm water use efficiency and hence water productivity can be improved by moving to a more efficient irrigation system. Sprinkler and drip irrigation can save non-effective water loss [10]. Modernization and optimization of irrigation systems can contribute to increasing water productivity [11].

Management allowed depletion (MAD) is the fraction of the total available soil water which is most easily extracted by the plant roots without creating stress. The water content approaching permanent wilting point (PWP) cannot be easily extracted by the plant roots. As evapotranspiration occurs, the soil water reservoir begins to be depleted. As the soil dries, the remaining water is held more tightly by capillary forces in the soil, making it more difficult for the plant to extract it. For this reason, ET will start to decrease long before the PWP is reached. Since the lowest ET will generally reduce yields, growers should irrigate before the root zone water content reaches the level that restricts ET [12]. The study was conducted to evaluate the effects of furrow and drip irrigation methods under different soil moisture depletion levels on yield, yield components and water productivity of onion.

\section{Materials and Methods}

The study was conducted at Melkasa Agricultural Research Center during off season (2018 cropping season). The center is located in Oromia regional state, Adama woreda, central rift valley of Ethiopia, at a geographical location of $8^{\circ} 24^{\prime} 36^{\prime \prime}-8^{\circ} 26^{\prime} 24^{\prime \prime} \mathrm{N}$ latitude and 39॰19'12" $39^{\circ} 19^{\prime} 48^{\prime \prime}$ E longitude, with an average altitude of $1,550 \mathrm{~m}$ above mean sea level (Figure 1). The average annual rainfall of the area was $824.92 \mathrm{~mm}$. The site has a mean maximum and minimum temperature of $28.72^{\circ} \mathrm{C}$ and $13.82^{\circ} \mathrm{C}$, respectively.

Table 1. The long-term (1977-2017) monthly climate data of MARC.

\begin{tabular}{|c|c|c|c|c|c|c|c|}
\hline Month & $\operatorname{Tmin}\left({ }^{\circ} \mathbf{C}\right)$ & $\operatorname{Tmax}\left({ }^{\circ} \mathrm{C}\right)$ & RH (\%) & $\mathrm{U}_{2}(\mathrm{~m} / \mathrm{s})$ & n (hr) & RF (mm) & ETo (mm/day) \\
\hline January & 11.71 & 27.93 & 51.04 & 8.59 & 9.05 & 16.02 & 6.30 \\
\hline February & 13.42 & 29.12 & 48.74 & 9.08 & 9.17 & 24.05 & 7.14 \\
\hline March & 15.06 & 30.47 & 49.21 & 8.63 & 8.52 & 52.31 & 7.47 \\
\hline April & 15.47 & 30.49 & 50.76 & 7.84 & 8.23 & 53.88 & 7.20 \\
\hline May & 15.54 & 31.00 & 51.17 & 7.46 & 8.76 & 61.03 & 7.13 \\
\hline June & 16.37 & 30.19 & 53.11 & 9.00 & 8.36 & 69.01 & 7.25 \\
\hline July & 15.67 & 26.85 & 66.36 & 9.07 & 7.03 & 204.21 & 5.39 \\
\hline September & 14.47 & 27.62 & 65.76 & 4.88 & 7.32 & 99.75 & 4.90 \\
\hline October & 11.68 & 28.76 & 50.02 & 6.58 & 8.66 & 39.35 & 6.22 \\
\hline November & 10.76 & 28.33 & 46.67 & 8.26 & 9.60 & 12.64 & 6.63 \\
\hline December & 10.37 & 27.55 & 48.76 & 8.87 & 9.47 & 9.60 & 6.33 \\
\hline Average & 13.82 & 28.72 & 54.23 & 7.94 & 8.44 & 68.74 & 6.40 \\
\hline
\end{tabular}

$\mathrm{T}_{\max }$ and $\mathrm{T}_{\min }=$ maximum and minimum air temperature $\left({ }^{\circ} \mathrm{C}\right)$ respectively, $\mathrm{RH}=$ relative humidity $(\%)$, $\mathrm{u}=$ Wind speed at $2 \mathrm{~m}$ height $(\mathrm{m} / \mathrm{sec})$, $\mathrm{n}=$ sunshine hour $(\mathrm{hr})$ and $\mathrm{ETo}=$ potential evapotranspiration ( $\mathrm{mm} /$ day).

Source: Melkasa Agricultural Research Center (MARC) meteorological station. 


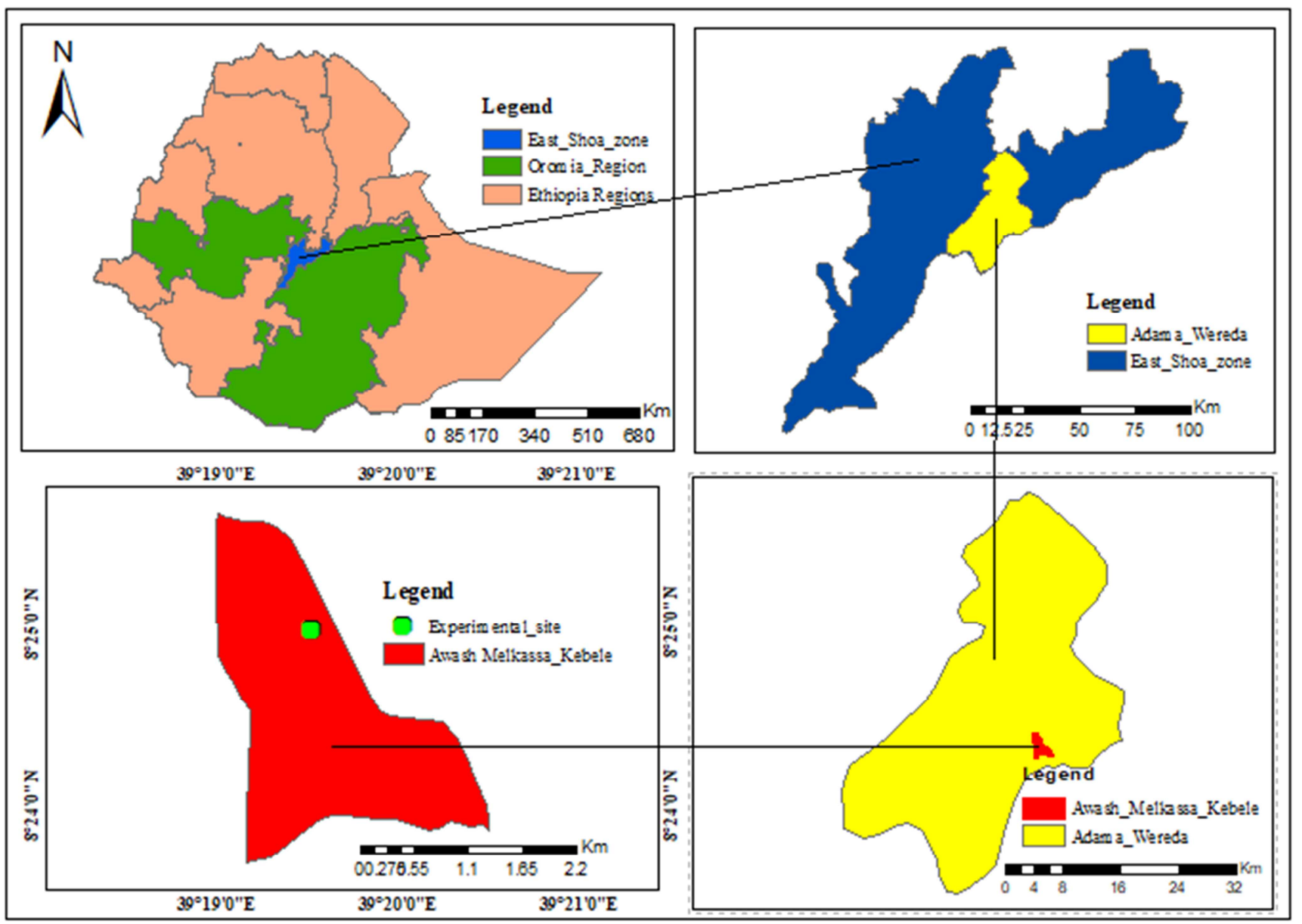

Figure 1. Location of the study area (MARC).

\subsection{Experimental Design and Treatments}

Treatments of the experiment consisted of two irrigation systems: furrow irrigation (FI) and drip irrigation (DI) and three level of management allowed depletion (MAD) viz., $120 \% \mathrm{MAD}, 100 \% \mathrm{MAD}$ and $80 \% \mathrm{MAD}$. The experimental design was split plot in a randomized complete block design with three replications, in which irrigation methods were assigned as the main plots and level of MAD as sub-plots. Each experimental plot has a plot size of $3.6 \mathrm{~m}$ by $4 \mathrm{~m}$ to accommodate five furrows with a spacing of $60 \mathrm{~cm}$. The plots and blocks had a buffer zone of $1 \mathrm{~m}$ and $1.5 \mathrm{~m}$ between plots and blocks, respectively.

Table 2. Treatments combination and descriptions.

\begin{tabular}{ll}
\hline Treatment & Description \\
\hline T1 & Furrow irrigation method with $120 \%$ of MAD level \\
T2 & Furrow irrigation method with $100 \%$ of MAD level \\
T3 & Furrow irrigation method with $80 \%$ of MAD level \\
T4 & Drip irrigation method with $120 \%$ of MAD level \\
T5 & Drip irrigation method with $100 \%$ of MAD level \\
T6 & Drip irrigation method with $80 \%$ of MAD level \\
\hline
\end{tabular}

\subsection{Installation of Drip Irrigation Sets}

The drip irrigation system was designed and installed in such a way to maintain the required pressure at the end of the plot so that uniform water distribution at each emitter was obtained. Five drip laterals per plot having $4 \mathrm{~m}$ length, $60 \mathrm{~cm}$ spacing between laterals and $20 \mathrm{~cm}$ interval between emitters with discharge rates of $2 \mathrm{lit} / \mathrm{hr}$ were installed. The drip lines (laterals) of $16 \mathrm{~mm}$ diameter were unrolled and laid along the middle of two rows of the crop separated by $20 \mathrm{~cm}$ spacing. The drip system was served by water storage tank placed at 2 $\mathrm{m}$ height from the ground. The water distribution system components diameter of $32 \mathrm{~mm}$ mainline, $25 \mathrm{~mm}$ sub-main line were laid and connected to the water container to the individual drip lines. Gate valve was fixed on a mainline next to the filter to control the water flow to the field. The irrigation water delivered to each experimental plot was controlled by gate valve fixed on the manifold.

\subsection{Crop establishment and Management Practices}

Onion (Allium cepa $\mathrm{L}$ ) seed variety Nafis was used as seed material for the experiment. The seeds were sown on wellprepared nursery fields on January 24, 2018. The seedlings were then transplanted on March 18, 2018, on well-prepared experimental plots on both sides of ridges at row and plant spacing of $20 \mathrm{~cm}$ and $10 \mathrm{~cm}$, respectively. Each plot consisted of ten rows with a total number of 400 plants per plot. After transplanting, up to the tenth day, common irrigation $(100 \% \mathrm{ETc})$ was applied to all plots for the better 
plant establishment. The control treatment (100\% MAD) received irrigation water at management allowed soil moisture depletion $(\rho=0.25)$ of the total available soil moisture throughout the crop growth stage. Other treatments received $120 \%$ and $80 \%$ of the control treatment.

Weeding and cultivation were performed by hand hoeing when deemed necessary. The recommended rate of $200 \mathrm{~kg} / \mathrm{ha}$ DAP and $100 \mathrm{~kg} / \mathrm{ha}$ Urea were uniformly applied to the plots. DAP was applied at planting time only whilst urea was applied in split application, half at planting and another half fifteen days after transplanting [13]. The chemicals Selecron and Redomil Gold were used according to the recommended rate, to protect the crop against harmful insects and fungus. The growing period of the crop was categorized into four distinct growth stages based on FAO's recommendation [14]. Initial (20 days), crop development (25 days), mid-season (45 days) and late season (20 days).

\subsection{Irrigation Water Management}

Crop water requirement

The reference evapotranspiration (ETo) was estimated using the FAO Penman-Monteith method. The crop water requirements $(\mathrm{ETc})$ over the growing season were determined by multiplying the daily ETo value with the $\mathrm{Kc}$-value. The $\mathrm{Kc}$ value was taken as $\mathrm{K}_{\mathrm{c} \text { ini }}(0.5), \mathrm{K}_{\mathrm{c} \text { mid }}(1.05)$ and $\mathrm{K}_{\mathrm{c} \text { end }}$ $(0.85)$ respectively. For developmental stage $\left(\mathrm{K}_{\mathrm{c} \text { dev }}\right)$ and lateseason $\left(\mathrm{K}_{\mathrm{c} \text { late }}\right), \mathrm{K}_{\mathrm{c}}$ values were determined by graphically [14].

$$
E T c=K c \times E T o
$$

where: $\mathrm{ET}_{\mathrm{c}}$ is crop evapotranspiration $(\mathrm{mm} /$ day), ETo is reference crop evapotranspiration $(\mathrm{mm} /$ day) and $\mathrm{Kc}=\mathrm{crop}$ coefficient.

Irrigation water application

The soil water use in the experiment was obtained from routine measurements of soil moisture content by the gravimetric method. In this method, soil samples were collected with soil auger just before and after irrigation to compute soil water contents. The wet soil samples were placed in an oven dry at a temperature of $105{ }^{\circ} \mathrm{C}$ and dried for 24 hours. The gravimetric water content was converted to equivalent depth (D) from the expression:

$$
\mathrm{D}=\left(\frac{\mathrm{W}_{\mathrm{w}}-\mathrm{W}_{\mathrm{d}}}{W_{d}}\right) \times \mathrm{BD} \times \mathrm{drz}
$$

where: $\mathrm{D}$ is the depth of available soil moisture in $\mathrm{mm}, \mathrm{W}_{\mathrm{w}}$ is wet soil weight in gm, $\mathrm{W}_{\mathrm{d}}$ is dry soil weight in gm, BD is the soil dry bulk density in $\mathrm{g} \mathrm{cm}^{-3}$ and drz is the sampling depth within the crop root depth in $\mathrm{mm}$.

The soil moisture depleted between irrigation was obtained from:

$$
d n=F c-D
$$

where: $\mathrm{dn}$ is the net irrigation requirement in $\mathrm{mm}$ and $\mathrm{FC}$ is the soil moisture content at field capacity in $\mathrm{mm}$.

Irrigation scheduling
Total available water (TAW) was computed from the soil moisture content at field capacity and permanent wilting point using the following equation as indicated by Allen et al [14].

$$
T A W=(F C-P W P) \times B D \times D_{z}
$$

where: TAW is the total available water in the root zone (mm), FC and PWP are moisture content at field capacity and permanent wilting point $(\%)$, respectively and $D_{z}$ is the maximum effective root depth of onion at times of irrigations $(\mathrm{mm})$.

For maximum crop production, the irrigation schedule was fixed based on MAD. The value of MAD was used as a guide for deciding when to irrigate. Irrigation water was applied when the soil water deficit approaches or equal MAD to minimize water stress on the crop. The MAD for onion used in this study was $25 \%(\rho=0.25)$ of the total available soil moisture [8]. Readily available water (RAW) was computed from the expression:

$$
\mathrm{RAW}=\mathrm{TAW} \times \rho
$$

where: RAW is in mm, $\rho$ is allowable permissible soil moisture depletion and TAW is in $\mathrm{mm}$.

Irrigation frequency which is defined as the frequency of applying water to a crop at a certain stage of growth was estimated using the following equation [15].

$$
f=\frac{R A W}{E T C}
$$

where: $\mathrm{f}$ is irrigation frequency in day, RAW is in $\mathrm{mm}$, and ETc is in $\mathrm{mm}$.

The net depth of irrigation supplied at any time was obtained from a simplified water balance equation expressed as:

$$
I_{n}=E T c-P_{e f f}
$$

where: $I_{n}$ is the net irrigation depth in $\mathrm{mm}$, ETc is in $\mathrm{mm}$ and $\mathrm{P}_{\text {eff }}$ is effective rainfall in $\mathrm{mm}$.

The effective rainfall was estimated using the method given in CROPWAT software using dependable rain (FAO formula).

$$
\begin{aligned}
& \mathrm{P}_{\mathrm{eff}}=0.6 \times \mathrm{P}-10 \text { for month } \leq 70 \mathrm{~mm} \\
& \mathrm{P}_{\mathrm{eff}}=0.8 \times \mathrm{P}-24 \text { for month }>70 \mathrm{~mm}
\end{aligned}
$$

where: $\mathrm{P}$ is rainfall in $\mathrm{mm}$ and $\mathrm{P}_{\text {eff }}$ is effective rainfall in $\mathrm{mm}$

The gross irrigation requirement was computed by adopting a field application efficiency of $60 \%$ for furrow and $90 \%$ for drip irrigation method [16].

$$
I_{g}=\frac{I_{n}}{E_{a}}
$$

where: $I_{g}$ is gross irrigation depth in $m m, I_{n}$ is in $m m$ and $E_{a}$ is application efficiency (\%).

In the case of furrow irrigation, the determined amount of irrigation water applied to the plots was measured using a 3 
inch Parshall flume. Accordingly, the time required to deliver the desired depth of water into each plot was calculated using the equation given below.

$$
T=\frac{A \times I_{g}}{6 \times q}
$$

where: $\mathrm{T}$ is application time $(\mathrm{min}), \mathrm{I}_{\mathrm{g}}$ is in $\mathrm{mm}, \mathrm{A}$ is the area of the experimental plot $\left(\mathrm{m}^{2}\right)$, and $\mathrm{q}$ is flow rate $(1 / \mathrm{s})$ at specific Parshall flume head.

In the case of drip irrigation, the gross irrigation requirement was computed as:

$$
I_{g}=\frac{I_{n} \times W a}{E_{a}}
$$

where: $I_{g}$ is gross irrigation requirement in $\mathrm{mm}$, wa is the wetting area in $\%, I_{n}$ is the net irrigation depth in $\mathrm{mm}$ and $\mathrm{Ea}$ is drip irrigation application efficiency in $\%$.

Time required to deliver the desired depth of water into each plot was computed from:

$$
T=\frac{\operatorname{Ig} \times A}{N l \times N e \times q}
$$

where, $\mathrm{T}$ is time in hours, $\mathrm{A}$ is the plot area in $\mathrm{m}^{2}, \mathrm{Nl}$ is the number of lateral, $\mathrm{Ne}$ is number of emitters per lateral and $\mathrm{q}$ is emitter discharge in $1 / \mathrm{hr}$.

\subsection{Data Collection}

\section{Climatic data}

Daily climatic data such as rain fall, temperature, relative humidity, sunshine hours and wind speed were obtained from meteorological station of the MARC. These data were used to determine the ETo and effective rainfall by CROPWAT 8.0 software.

Soil data

Representative soil samples were taken to investigate some properties of the soils such as moisture content at field capacity (FC) and permanent wilting point (PWP), bulk density $\left(\rho_{\mathrm{b}}\right)$, organic matter $(\mathrm{OM})$, texture, electrical conductivity (EC) and $(\mathrm{pH})$ of the study area. The samples were taken at $15 \mathrm{~cm}$ depth interval within the effective root zone, which was considered to be $50 \mathrm{~cm}$ for onion. The analysis was conducted at Oromia Water Works Design and Supervision Enterprise Laboratory. Before the experimental work was started, the soil infiltration test was determined using double ring infiltrometer.

Soil $\rho_{\mathrm{b}}$ was determined by taking undisturbed soil samples using a known volume of core sampler. The soil samples were oven dried for 24 hours at a temperature of $105^{\circ} \mathrm{C}$. Then $\rho_{\mathrm{b}}$ was determined as [17]:

$$
\rho b=\frac{M_{s}}{V_{b}}
$$

where $M_{s}=$ the mass of soil after oven dry $(g)$ and $V_{b}=$ bulk volume of soil $\left(\mathrm{cm}^{3}\right), \rho_{b}$ is in $\mathrm{g} / \mathrm{cm}^{3}$.

Drip uniformity parameters

The performance of drip irrigation system was evaluated using commonly used performance indicators such as distribution uniformity and coefficient of uniformity.

Distribution uniformity $(\mathrm{Du})$

DU is the ratio between the average discharge in the quarter receiving less water and the average discharge at the system level. It is used to describe the predicted emitter flow variation along a lateral line. DU (\%) was estimated as:

$$
D U=\frac{\bar{q} \text { lowest } 25 \%}{\bar{q}} \times 100
$$

where, lowest $25 \%$ is average of the lowest quarter discharge, is average discharge

Coefficient of uniformity (CU)

It is also known as Christiansen's uniformity coefficient is the ratio of the difference between the average amount applied and the average deviation from the average amount applied to the average amount applied.

$$
C U=\left(1-\left(\frac{\sum\left|q_{i}-\bar{q}\right|}{n \bar{q}}\right)\right) \times 100
$$

where: $\mathrm{q}_{\mathrm{i}}$ is dripper discharge,=average discharge and $\mathrm{n}=$ number of drippers

Agronomic data

Agronomic data including plant height and a number of leaves per plant were taken from five plants randomly tagged from each experimental unit excluding the border rows and border plants, in the central rows. Plant height was taken by measuring the main stem height from the ground up to the tip of the leaf with the help of a ruler. All completely developed leaves of the same plants were counted. The leaf length of the same plants was measured from the leaf base to the tip. Yield parameters data such as bulb height, bulb diameter, and bulb weight were also recorded from the same plants used for recording previous parameters. The increase in yield due to drip irrigation was computed using the following equation [18]:

$$
\text { Increase in yield }=\left(\frac{Y_{1}-Y_{2}}{Y_{1}}\right) \times 100
$$

where, $\mathrm{Y}_{1}$ and $\mathrm{Y}_{2}$ are yields obtained from drip and furrow irrigation respectively in $\mathrm{kg} / \mathrm{ha}$.

Water productivity

Water productivity (WP) was determined by dividing the total onion bulb yield to the net amount of irrigation water applied to the crop [19]:

$$
\mathrm{WP}=\frac{\mathrm{Y}}{\mathrm{ETc}}
$$

where: WP is water productivity $\left(\mathrm{Kg} / \mathrm{m}^{3}\right), \mathrm{Y}$ is total bulb yield per unit area $(\mathrm{Kg} / \mathrm{ha})$, ETc is crop evapotranspiration (mm).

Water saving

The water saving in drip irrigation method over furrow irrigation method was calculated as:

$$
W_{s}=\frac{W_{f}-W_{d}}{W_{f}} \times 100
$$

where: $\mathrm{W}_{\mathrm{s}}$ is water saving $(\%), \mathrm{W}_{\mathrm{f}}$ and $\mathrm{W}_{\mathrm{d}}$ are total water 
used in furrow and drip irrigation method $\left(\mathrm{m}^{3} / \mathrm{ha}\right)$.

\subsection{Data Analysis}

Data collected were subjected to statistical ANOVA appropriate to split plot in RCBD using SAS 9.0 software. Whenever treatment effects were found significant, treatment means were compared using the least significant difference (LSD) method. Pearson correlation analysis was also used to determine the association of onion bulb yield and yield components.

\section{Results and Discussions}

\subsection{Soil Characteristics at the Study Area}

The particle size distribution of the soils at experimental site at different soil depths were presented in table 3 . The percent particle size determination revealed that the soil texture is dominated by loam.

Table 3. Summarized soil particle size distribution.

\begin{tabular}{lllll}
\hline \multirow{2}{*}{ Soil depth (cm) } & \multicolumn{2}{l}{$\%$ Particle size distribution } & Clay (\%) (<0.002) \\
\cline { 2 - 5 } & Sand (\%) (2-0.05) & Silt (\%) (0.05-0.002) & 26 & Textural class \\
\hline $0-15$ & 36 & 38 & 26 & Loam \\
$15-30$ & 30 & 44 & 24 & Loam \\
$30-45$ & 36 & 40 & 30 & Clay loam \\
$45-60$ & 34 & 36 & 26.5 & Loam \\
Average & 34 & 39.5 & & \\
\hline
\end{tabular}

The bulk density of soil of the area shows a variation with depth (Table 4). It varies between 1.09 to $1.23 \mathrm{gcm}^{-3}$ and generally; the top surface soil has slightly lower bulk density than the subsurface. This may be due to compaction of soil in the lower depth of soil layer. The weighted average bulk density of the soil in the experimental station was $1.14 \mathrm{gcm}^{-3}$.

Table 4. Soil moisture constants and bulk density of experimental site.

\begin{tabular}{lllll}
\hline $\begin{array}{l}\text { Sampling depth } \\
\text { (cm) }\end{array}$ & $\begin{array}{l}\text { Bulk density } \\
\left.\text { (gcm }^{-3}\right)\end{array}$ & $\begin{array}{l}\text { FC (\%) } \\
\text { wt.) }\end{array}$ & $\begin{array}{l}\text { PWP } \\
(\%)\end{array}$ & $\begin{array}{l}\text { TAWt. } \\
(\mathbf{m m} / \mathbf{m})\end{array}$ \\
\hline $0-15$ & 1.09 & 35.5 & 20.6 & 162.4 \\
$15-30$ & 1.12 & 37 & 21.2 & 177.0 \\
$30-45$ & 1.12 & 39 & 21.8 & 192.6 \\
$45-60$ & 1.23 & 39.9 & 22.8 & 210.3 \\
Mean & 1.14 & 37.8 & 21.6 & 185.6 \\
\hline
\end{tabular}

The moisture content at FC and PWP varies with depth that ranged between $35.5 \%$ and $39.9 \%$ and $20.6 \%$ and $22.8 \%$ respectively on a weight basis. The top soil surface was having lower values than subsurface soil layers for both parameters. The average value TAW was found to be 185.6 $\mathrm{mm}$ per meter depth of soil (Table 4). The basic infiltration rate was about $12 \mathrm{~mm} / \mathrm{hr}$ (Figure 2). This rate of infiltration is in the range of infiltration characteristics of loam soils [20].

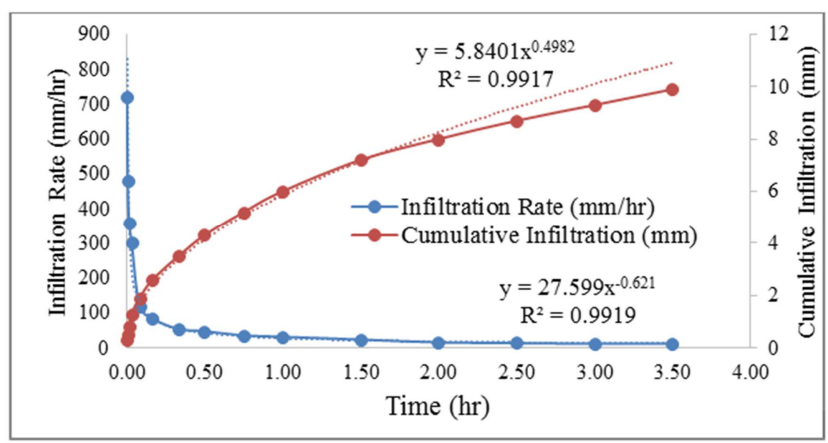

Figure 2. Soil infiltration rate of the experimental field.
As shown in table 5, the organic matter (OM) content decline with depth. The highest $(2.07 \%)$ and the lowest (1.5\%) OM contents were recorded at the surface $(0-15 \mathrm{~cm}$ depth) and bottom (45-60 cm soil depth) layers respectively. The average OM content of the soil was about $1.8 \%$. The average value of the $\mathrm{PH}$ of the soil was about 6.47 . This showed that the $\mathrm{PH}$ of the site is nearly neutral and suitable for onion production [13]. The average value of the ECe of the soil was about $0.16 \mathrm{ds} / \mathrm{m}$.

Table 5. Selected soil chemical properties of the surface of the experimental field.

\begin{tabular}{llll}
\hline Soil depth $(\mathbf{c m})$ & PH & ECe $(\mathbf{d s} / \mathbf{m})$ & OM $(\%)$ \\
\hline $0-15$ & 5.81 & 0.18 & 2.07 \\
$15-30$ & 6.65 & 0.16 & 1.88 \\
$30-45$ & 6.50 & 0.15 & 1.74 \\
$45-60$ & 6.91 & 0.16 & 1.50 \\
Average & 6.47 & 0.16 & 1.80 \\
\hline
\end{tabular}

\subsection{Distribution Uniformity of Drip Emitters}

Analysis of data on emitter discharge observation under all parameters has shown better performance. The values of $\mathrm{Du}$ and $\mathrm{Cu}$ were $97.57 \%$ and $98.20 \%$, respectively (Table 6). The DU was excellent according to Bralts [21] emitter flow variation was acceptable.

Table 6. Uniformity of drip irrigation.

\begin{tabular}{lll}
\hline Parameters & Units & Average \\
\hline Distribution uniformities $(\mathrm{Du})$ & $\%$ & 97.57 \\
Emitter flow variation $(\mathrm{qv})$ & $\%$ & 6.77 \\
Coefficient of variation $(\mathrm{Cv})$ & $\%$ & 2.10 \\
Uniformity coefficient $(\mathrm{Cu})$ & $\%$ & 98.20 \\
\hline
\end{tabular}

\subsection{Crop Water Requirement}

The crop water requirements of onion under FI and DI with $100 \%$ MAD were $498.65 \mathrm{~mm}$ and $326.66 \mathrm{~mm}$, respectively. The applied common irrigation water was 27.26 $\mathrm{mm}$ which was applied two times from transplanting up to 
ten days of crop growth. Relatively $2.59 \%, 59.51 \%, 60 \%$ and $61.04 \%$ of water were saved due to T3, T4, T5 and T6 respectively as compared to $\mathrm{T} 2$.

Table 7. Crop and irrigation water requirement of onion crop.

\begin{tabular}{lll}
\hline Parameters & Units & Average \\
\hline Distribution uniformities $(\mathrm{Du})$ & $\%$ & 97.57 \\
Emitter flow variation $\left(\mathrm{q}_{\mathrm{v}}\right)$ & $\%$ & 6.77 \\
Coefficient of variation $(\mathrm{Cv})$ & $\%$ & 2.10 \\
Uniformity coefficient $(\mathrm{Cu})$ & $\%$ & 98.20 \\
\hline
\end{tabular}

$\mathrm{IRn}=$ net irrigation requirement, $\mathrm{IRg}=$ gross irrigation requirement, $\mathrm{CWR}=$ crop water requirement, $\mathrm{P}_{\mathrm{ef}}=$ effective rainfall and $\mathrm{Rws}=$ relative water saved.

\subsection{Effects of Irrigation Methods and MAD Levels on Crop Growth}

Number of green leaves per plant

The ANOVA indicated that there was a significant $(\mathrm{P}<0.05)$ effect on number of leaves per plant due to irrigation methods. As shown in table 8, the highest leaf number per plant (13) was observed from the DI method while lower number of leaves per plant (12) was obtained from FI method. Based on the results, the DI method resulted in increased leaf number by $7.7 \%$ as compared to FI method. Bagali et al [5] also reported that scheduling of DI significantly increased the growth parameters.

Table 8. Effects of irrigation methods and MAD levels on crop physiology.

\begin{tabular}{llll}
\hline Treatments & $\begin{array}{l}\text { Number of Leaves } \\
\text { per plant }\end{array}$ & $\begin{array}{l}\text { Plant height } \\
(\mathbf{c m})\end{array}$ & $\begin{array}{l}\text { Leaf height } \\
(\mathbf{c m})\end{array}$ \\
\hline $120 \% \mathrm{MAD}$ & $11^{\mathrm{c}}$ & $61.40^{\mathrm{b}}$ & $56.93^{\mathrm{b}}$ \\
$100 \% \mathrm{MAD}$ & $12^{\mathrm{b}}$ & $64.73^{\mathrm{ab}}$ & $60.40^{\mathrm{ab}}$ \\
$80 \% \mathrm{MAD}$ & $13^{\mathrm{a}}$ & $67.30^{\mathrm{a}}$ & $62.83^{\mathrm{a}}$ \\
LSD (0.05) & 0.39 & 3.56 & 3.62 \\
CV $(\%)$ & 2.39 & 4.15 & 4.53 \\
F & $12^{\mathrm{b}}$ & $62.60^{\mathrm{b}}$ & $58.27^{\mathrm{b}}$ \\
D & $13^{\mathrm{a}}$ & $66.36^{\mathrm{a}}$ & $61.84^{\mathrm{a}}$ \\
LSD $(0.05)$ & 0.58 & 2.74 & 2.16 \\
CV $(\%)$ & 2.36 & 2.10 & 1.77 \\
\hline
\end{tabular}

*Means followed by the same letter in a column per treatment factor are not significantly different from each other at a $5 \%$ probability level.

The ANOVA also has shown that the MAD levels had a highly significant $(\mathrm{P}<0.01)$ effect on a number of green leaves per plant. The result indicated that the highest green leaf number per plant (13) was observed at $80 \%$ MAD while the lowest number of leaf per plant (11) was observed from $120 \%$ MAD level. The result indicated that it is preferable to irrigate onion at shorter interval than recommended. Similar results of improved crop growth with irrigation or rewatering near field capacity were reported by Kumar et al [22] for growth parameters. The ANOVA also showed that the interaction effect of irrigation methods and MAD levels was not significant for the number of green leaf per plant.

Plant height

The ANOVA indicated that there was significant $(\mathrm{p}<0.05)$ effect on plant height due to irrigation application methods and MAD levels. The mean value of plant height recorded from DI method was higher than FI. This finding agrees with that of Bhasker et al [23] who reported that maximum plant height was recorded under DI method.

As shown in table 8 , the highest plant height $(67.30 \mathrm{~cm})$ was obtained from $80 \% \mathrm{MAD}$ level and was not significantly different from $100 \%$ MAD level, while the shortest mean plant height $(61.40 \mathrm{~cm})$ was observed on the application of $120 \%$ MAD level and statistically not different with $100 \%$ MAD. The reason for the better performance of this growth parameter due to the shorter interval of irrigation may be attributed to optimum soil water-air-balance around plant root zone. This study outcome is in line with the research that was conducted by El-Noemani et al [24] indicated that soil water supply is directly proportional with plant height growth. However, the ANOVA showed that the interaction of irrigation methods and MAD levels had no significant effect on plant height.

\subsection{Effects of Irrigation Methods and MAD Levels on Yield and Yield Parameters}

Total bulb yield

The ANOVA has shown that irrigation methods, MAD levels and their interaction had a highly significant $(\mathrm{P}<0.01)$ effect on total bulb yield. As shown in table 9, the maximum total bulb yield $(41.76 \mathrm{t} / \mathrm{ha})$ was obtained under drip irrigation method with $80 \%$ of management allowed deficit which was significantly different from all other treatments. The lowest total bulb yield (34.48 t/ha) was obtained under Furrow irrigation method with $120 \%$ of management allowed deficit. The total yield obtained under furrow irrigation method with $100 \%$ of management allowed deficit had no significant difference from drip irrigation method with $120 \%$ of management allowed deficit and total yield obtained under Furrow irrigation method with $80 \%$ of management allowed deficit had not significant difference from drip irrigation method with $100 \%$ of management allowed deficit. High irrigation frequency might provide desirable conditions for water movement in soil and for uptake by roots [25]. Several experiments have shown positive responses in some crops to high frequency drip irrigation $[25,26]$.

Table 9. Effect of irrigation method and MAD levels on total onion bulb yield $(\mathrm{t} / \mathrm{ha})$.

\begin{tabular}{|c|c|c|c|c|}
\hline \multirow{2}{*}{$\begin{array}{l}\text { Irrigation } \\
\text { methods }\end{array}$} & \multicolumn{4}{|c|}{ MAD levels } \\
\hline & $120 \%$ & $100 \%$ & $80 \%$ & Mean \\
\hline Furrow & $34.48^{\mathrm{d}}$ & $37.14^{\mathrm{c}}$ & $40.60^{\mathrm{b}}$ & 37.41 \\
\hline Drip & $36.35^{\mathrm{c}}$ & $40.74^{b}$ & $41.76^{\mathrm{a}}$ & 39.62 \\
\hline Mean & 35.41 & 38.94 & 41.18 & 38.51 \\
\hline $\operatorname{LSD}(0.05)$ & 0.96 & & & \\
\hline CV $(\%)$ & 1.16 & & & \\
\hline
\end{tabular}

*Means followed by the same letter are not significantly different from each other at a $1 \%$ probability level.

Marketable bulb yield

The statistical analysis indicated that irrigation methods, MAD levels and their interaction had a highly significant $(\mathrm{P}<0.01)$ effect on marketable onion bulb yield. As shown in table 10, the highest marketable bulb yield of $38.39 \mathrm{t} / \mathrm{ha}$ was obtained from drip irrigation method with $80 \%$ of 
management allowed deficit and significantly different to all other treatments. The lowest yield of $31.6 \mathrm{t} / \mathrm{ha}$ was obtained from Furrow irrigation method with $120 \%$ of management allowed deficit and significantly different to all other treatments. The bulb yield obtained from Furrow irrigation method with $100 \%$ of management allowed deficit had no significant difference with drip irrigation method with $120 \%$ of management allowed deficit. The bulb yield obtained from Furrow irrigation method with $80 \%$ of management allowed deficit had no significant difference with irrigation method with $100 \%$ of management allowed deficit. The current result was in confirmation with study result of Bagali et al [5] who reported that scheduling of drip irrigation at shorter intervals significantly increased the growth parameters and significantly higher bulb yield as compared to flood irrigation. Onion performs better when irrigation is given on depletion of 15-20 percent soil moisture of the field capacity. This is the reason for higher yield by the treatments with drip irrigation method at shorter intervals of irrigations.

Table 10. Effect of irrigation method and MAD level on marketable bulb yield $(t / h a)$.

\begin{tabular}{|c|c|c|c|c|}
\hline \multirow{2}{*}{$\begin{array}{l}\text { Irrigation } \\
\text { methods }\end{array}$} & \multicolumn{4}{|c|}{ MAD levels } \\
\hline & $120 \%$ & $100 \%$ & $80 \%$ & Mean \\
\hline Furrow & $31.60^{\mathrm{d}}$ & $34.05^{\mathrm{c}}$ & $37.30^{\mathrm{b}}$ & 34.32 \\
\hline Drip & $33.28^{\mathrm{c}}$ & $37.39^{\mathrm{b}}$ & $38.39^{\mathrm{a}}$ & 36.35 \\
\hline Mean & 32.44 & 35.72 & 37.85 & 35.34 \\
\hline $\operatorname{LSD}(0.05)$ & 0.92 & & & \\
\hline CV (\%) & 1.17 & & & \\
\hline
\end{tabular}

*Means followed by the same letter are not significantly different from each other at a $1 \%$ probability level.

\section{Bulb diameter}

The ANOVA indicated that MAD level had a highly significant $(\mathrm{P}<0.01)$ effect on bulb diameter. The irrigation method and interaction had a significant $(\mathrm{P}<0.05)$ effect on bulb diameter. As depicted in table 11, the highest bulb diameter of $6.02 \mathrm{~cm}$ was obtained from T6 and significantly different from all other treatments. This result was in line with the result of Enchalew et al [27]. The lowest bulb diameter of $5.11 \mathrm{~cm}$ was obtained from $\mathrm{T} 1$ and significantly different from all other treatments. The bulb diameter obtained from $\mathrm{T} 2 \mathrm{had}$ no significant difference from that of $\mathrm{T} 3$ and $\mathrm{T} 5$. The result indicated that it is preferable to irrigate onion at shorter interval with drip irrigation than furrow irrigation method. This may be because of moisture available in the root zone was enough for nutrient availability for the crop.

Table 11. Effect of irrigation method and MAD level on bulb diameter (cm).

\begin{tabular}{|c|c|c|c|c|}
\hline \multirow{2}{*}{$\begin{array}{l}\text { Irrigation } \\
\text { methods }\end{array}$} & \multicolumn{4}{|c|}{ MAD levels } \\
\hline & $120 \%$ & $100 \%$ & $80 \%$ & Mean \\
\hline Furrow & $5.11^{\mathrm{d}}$ & $5.70^{\mathrm{b}}$ & $5.72^{b}$ & 5.51 \\
\hline Drip & $5.45^{\mathrm{c}}$ & $5.72^{b}$ & $6.02^{\mathrm{a}}$ & 5.73 \\
\hline Mean & 5.28 & 5.71 & 5.87 & 5.62 \\
\hline $\operatorname{LSD}(0.05)$ & 0.24 & & & \\
\hline CV (\%) & 1.75 & & & \\
\hline
\end{tabular}

*Means followed by the same letter are not significantly different from each other at a $1 \%$ and $5 \%$ probability level.

\section{Bulb height}

The ANOVA indicated that irrigation methods and MAD levels had a highly significant $(\mathrm{P}<0.01)$ effect on bulb height while the interaction was not significant. The bulb height for DI method was higher $(5.9 \mathrm{~cm})$ and highly significantly $(\mathrm{p}<0.01)$ different from that obtained from FI method $(5.7 \mathrm{~cm})$. DI method resulted in bulb height increment by $3.4 \%$ as compared to FI method. These results were in line with the results of Bagali et al [5]. As indicated in table 12 , the highest bulb height $(6 \mathrm{~cm})$ was obtained from $80 \%$ MAD level though it is not significantly different from that of $100 \%$ MAD level. The lowest bulb height $(5.53 \mathrm{~cm})$ was recorded from $120 \%$ MAD application and significantly different to all other MAD levels. Increased bulb height by ashorter intervals of irrigation may be due to the better performance of growth parameters like plant height and number of leaves. The shorter interval of irrigation ensures the optimum growth of the crop by assuring balanced water and nutrient supply throughout the crop growth period. The current result agreed with study result of Bagali et al [5].

Table 12. Effects of irrigation methods and MAD levels on bulb height.

\begin{tabular}{ll}
\hline Treatments & Bulb height $(\mathbf{c m})$ \\
\hline $120 \%$ MAD & $5.53^{\mathrm{b}}$ \\
$100 \%$ MAD & $5.87^{\mathrm{a}}$ \\
$80 \%$ MAD & $6.00^{\mathrm{a}}$ \\
LSD $(0.05)$ & 0.18 \\
F & $5.70^{\mathrm{b}}$ \\
D & $5.90^{\mathrm{a}}$ \\
LSD $(0.05)$ & 0.04 \\
CV $(\%)$ & 0.35 \\
\hline
\end{tabular}

*Means followed by the same letter in a column per treatment factor are not significantly different from each other at a $1 \%$ probability level.

\subsection{Water Productivity}

The ANOVA had shown that irrigation methods, MAD levels and their interaction had a highly significant $(\mathrm{P}<0.01)$ effect on water productivity (WP). The highest WP (13.05 $\mathrm{kg} / \mathrm{m}^{3}$ ) was obtained from T3 and statistically different for all other treatments. The lowest WP $\left(6.84 \mathrm{~kg} / \mathrm{m}^{3}\right)$ was obtained from FI method at $120 \%$ MAD application and significantly different to all other treatments. It is indicated that irrigating with DI method even at $120 \%$ MAD level resulted in higher WP than irrigating with FI method. As shown in table 13, the WP decreased as the MAD levels increased from $80 \%$ MAD to $120 \%$ MAD under both irrigation methods. This might be because of increase in yield when increased as frequent and light irrigation was applied by maintaining favorable soil moisture conditions throughout the cropping season. These results are in agreement with that of Teferi [18] reported the higher mean value of irrigation water use efficiency was observed under drip method with mean value of $7.1 \mathrm{~kg} \mathrm{~m}^{-3}$ which is $33.8 \%$ higher than that is obtained in furrow method $\left(4.7 \mathrm{~kg} \mathrm{~m}^{-3}\right)$. 
Table 13. Effect of irrigation methods and MAD levels on water productivity.

\begin{tabular}{lllll}
\hline Irrigation & MAD levels & & & \\
\cline { 2 - 5 } methods & $\mathbf{1 2 0 \%}$ MAD & $\mathbf{1 0 0 \%}$ MAD & $\mathbf{8 0 \%}$ MAD & Mean \\
\hline Furrow & $6.84^{\mathrm{f}}$ & $7.45^{\mathrm{e}}$ & $8.32^{\mathrm{d}}$ & 7.54 \\
Drip & $11.01^{\mathrm{c}}$ & $12.48^{\mathrm{b}}$ & $13.05^{\mathrm{a}}$ & 12.18 \\
Mean & 8.93 & 9.97 & 10.69 & 9.86 \\
LSD (0.05) & 0.24 & & & \\
CV (\%) & 1.28 & & & \\
\hline
\end{tabular}

\section{Conclusions and Recommendations}

\subsection{Conclusions}

Irrigation treatments had significant effect on yield and yield components considered in the study. Irrigation methods and MAD levels had a significant $(\mathrm{p}<0.05)$ effect on onion vegetative parameters like number of leaves per plant, plant height and leaf height and yield parameters like bulb diameter, bulb height, total bulb yield, marketable bulb yield, and water productivity. Further, their interaction had a significant effect on bulb diameter, total bulb yield, marketable bulb yield and water productivity. Nonetheless, they had no significant effect on number of leaves per plant, plant height, leaf height and bulb height. Generally, drip irrigation method was recorded higher vegetative and yield parameters than furrow irrigation method. The maximum total bulb yield (41.76 t/ha), marketable bulb yield (38.39 $\mathrm{t} / \mathrm{ha})$, bulb diameter $(6.02 \mathrm{~cm})$ and water productivity $(13.05$ $\mathrm{kg} / \mathrm{m}^{3}$ ) were observed from treatment combination of drip irrigation method and $80 \%$ MAD level (when water was applied at frequent intervals).

\subsection{Recommendation}

From the observation made during this research, the following points were further recommended:

a) The study suggests farmers in the study area, having limited amount of water for irrigation, should adopt drip irrigation method at the light and frequent (80\% MAD level), instead of surface irrigation method especially where high-value crops require frequent water applications to achieve a high production potential.

b) Growers will need to exercise flexibility in managing the rate, frequency, and duration of water supplies to successfully allocate limited water resource.

c) The experiment needs to be repeated across locations and time so as to see the residual effect of irrigation methods and MAD levels on onion.

d) The experiment was a one season and in one place. Hence, the experiment needs to be repeated across locations and time to improve the validity of the findings.

e) The gravimetric method was used to monitor soil moisture content, but it is also advisable to use other modern soil moisture monitoring instruments to effectively account the in-situ and real-time soil moisture to apply the right amount of water at the right time.

\section{References}

[1] Reddy R (2010). Irrigation Engineering. Gene-tech books, New Delhi.

[2] Kijne J, Barker R, Molden D (2003). Water Productivity in Agriculture: Limits and Opportunities for Improvement. IWMI, 1: 352 .

[3] Evans R, Sadler E (2008). Methods and technologies to improve efficiency of water use. Water Resour. Res. 44, W00E04, doi: 10.1029/2007WR006200.

[4] Mekonen A (2011). Deficit irrigation practices as alternative means of improving water use efficiencies in irrigated agriculture: Case study of maize crop at Arba Minch, Ethiopia. African J Agri. Res., 6 (2): 226-235.

[5] Bagali A, Patil H, Gule M, Patil R (2012). Effect of scheduling of drip irrigation on growth, yield and water use efficiencyof onion (Allium cepa L.). Karnataka J Agric. Sci., 25 (1): 116-119.

[6] FAO (Food and Agriculture Organization) (2013). Major food and agriculture commodities and producers-countries by commodity. www.fao.org.

[7] CSA (Central Statistical Agency) (2014). Agriculture Sample Survey. Central Statistical Agency. Vol. 1, Addis Ababa, Ethiopia.

[8] Doorenbos J, Kassam A (1996). Yield response to water. FAO irrigation and drainage paper 33, FAO, Rome Italy.

[9] Solaimalai A, Baskar M, Sadasakthf A, Subburamu K (2005). Fertigation in high-value crops; a review. Agric. Rev., 26 (1): 1-13.

[10] Ali M and Talukder M (2008). Increasing water productivity in crop production - A synthesis. Agri. Water Manag., 95: 201-1213. https://doi.org/10.1016/j.agwat.2008.06.008.

[11] Playán E, Mateos L (2006). Modernization and optimization of irrigation systems to increase water productivity. Agric. Water Manage, $80 \quad(1-3), \quad 100-116$. http://dx.doi:10.1016/j.agwat.2005.07.007.

[12] Palanisami K (2002). Economics of irrigation technology transfer and adoption. Tamil Nadu Agricultural University. Coimbatore, India. www.fao.org/docrep/W7314E/w7314eof, accessed on June 2017.

[13] Olani N, and Fikre M (2010). Onion seed production techniques. A Manual for Extension Agents and Seed Producers. FAO-Crop diversification and marketing development project. FAO, Asella, Ethiopia.

[14] Allen R, Pereira L, Raes, D Smith M (1998). Crop evapotranspiration guidelines for computing crop water requirements, FAO Irrigation and Drainage Paper 56, FAO, Rome, Italy.

[15] Doorenbos J, Pruitt W (1992). Crop water requirements. FAO irrigation and drainage paper 24, FAO, Rome Italy.

[16] Bresler E (1990). Drip irrigation technology in semi-arid regions. International co-operation J Irrig. Engin. and Rural planning, 19: 48-62.

[17] Arega M, Tena A (2012). Deficit Irrigation Application Using Center Pivot Sprinkler Irrigation for Onion Production. International Journal of Basic and Appl. Sci., 1 (2). 
[18] Teferi G (2015). Effect of Drip and Surface Irrigation Methods on Yield and Water Use Efficiency of Onion (Allium Cepa L.) under Semi-Arid Condition of Northern Ethiopia. Journal of Biology, Agriculture and Healthcare, 5 (14), 88-94.

[19] Illiassou N, Leonor R, and Raúl S (2014). Water use efficiency and water productivity in the Spanish irrigation district "Río Adaja". International Journal of Agricultural Policy and Research, 2 (12): 484-491. http://dx.doi.org/10.15739/IJAPR.021.

[20] Andreas P, Karen F (2002). Irrigation manual: Planning, development, monitoring and evaluation of irrigated agriculture with farmer participation, FAO, Harare, Zimbabwe.

[21] Bralts V (1986). Field Performance and evaluation: In trickle irrigation for crop production. Design, operation and management (Nakayama FS and Bucks SA, Eds.) Amsterdam, 216-240.

[22] Kumar S, Imtiyaz M, Kumar A, Singh R (2007). Response of onion (Allium cepa $\mathrm{L}$.) to different levels of irrigation water. Agric. Water Manage, 89 (1-2): 161-166. http://dx.doi:10.1016/j.agwat.2007.01.003.

[23] Bhasker P, Singh R, Gupta R, Sharma H, Gupta P (2018).
Effect of drip irrigation on growth and yield of onion (Allium cepa L.). J. Spices and Aromatic Crops. 27 (1): 32-37.

[24] El-Noemani A, Aboamera M, Aboellil A, Dewedar O (2009). Growth, yield, quality and water use efficiency of pea (Pisum sativum L.) plants as affected by evapotranspiration (ETo) and sprinkler height. J. Agric. Res., 34 (4): 1445-1466.

[25] Segal E, Ben-Gal A, Shani U (2000). Water availability and yield response to high-frequency micro-irrigation in sunflowers. The $6^{\text {th }}$ International Micro-irrigation congress on 'Micro irrigation technology for developing agriculture'. Conference papers, 22-27 October, South Africa.

[26] Sharmasarkar F, Sharmasarkar S, Miller S, Vance G, Zhang R (2001). Assessment of drip and flood irrigation on water and fertilizer use efficiencies for sugarbeets. Agric. Water Manage, 46 (3): 241-251.https://doi.org/10.1016/S03783774(00)00090-1.

[27] Enchalew B, Gebre SL, Rabo M, Hindaye B, Kedir M, Musa $Y$ and Shafi A (2016). 'Effect of Deficit Irrigation on Water Productivity of Onion (Allium cepal.) under Drip Irrigation', Irrigation and Drainage Systems Engineering, 5 (3), pp. 5-8. doi: $10.4172 / 2168-9768.1000172$ 